\title{
B-50 Phosphorylation and Polyphosphoinositide Metabolism in Nerve Growth Cone Membranes
}

\author{
C. O. M. Van Hooff, P. N. E. De Graan, A. B. Oestreicher, and W. H. Gispen \\ Division of Molecular Neurobiology, Rudolf Magnus Institute for Pharmacology and Institute of Molecular Biology and \\ Medical Biotechnology, University of Utrecht, $3584 \mathrm{CH}$ Utrecht, The Netherlands
}

\begin{abstract}
The neuron-specific phosphoprotein B-50 ( $M_{\mathrm{r}} 48 \mathrm{kDa}$, isoelectric point, IEP, 4.5), which is identical to GAP43, is a member of a family of growth-associated proteins. Protein B-50 is a major phosphoprotein in nerve growth cones isolated from fetal rat brain. In a growth cone particulate fraction (GCp), endogenous B-50 phosphorylation is $\mathrm{Ca}^{2+}$-dependent and is unaffected by CAMP. Addition of purified protein kinase C (PKC) to GCP enhances B-50 phosphorylation. In heat-inactivated GCp, B-50 is one of the major substrates of purified PKC. Endogenous B-50 phosphorylation in GCP is stimulated in a dose-dependent manner by $4 \beta$-phorbol diesters, known to activate PKC, but not by the inactive $4 \alpha$ phorbol derivatives.
\end{abstract}

In synaptic plasma membranes (SPM) isolated from adult rat brain, the degree of B-50 phosphorylation has been implicated in the modulation of receptor-mediated polyphosphoinositide (PPI) hydrolysis. In addition to B-50 and its kinase, PKC, the GCp fraction was also shown to contain all other components of such a modulatory system: the phosphatidylinositol 4-phosphate (PIP)-kinase, as shown on Western blots with affinity-purified IgGs against PIP-kinase, and the polyphosphoinosides, PIP and phosphatidylinositol 4,5-bisphosphate $\left(\right.$ PIP $\left._{2}\right)$, since the addition of $\gamma$-32P-ATP to the GCp fraction not only results in B-50 phosphorylation but also in the labeling of phosphatidic acid (PA), PIP, and PIP $\mathbf{2}^{\text {. }}$ $\mathrm{ACTH}_{1-24}$, which inhibits B-50 phosphorylation in the GCp fraction in a dose-dependent manner $\left(1 C_{50}=5 \times 10^{-6} \mathrm{M}\right)$, stimulates $\mathrm{PIP}_{2}$ labeling dose-dependently in the same preparation. This inverse relationship between the degree of B-50 phosphorylation and PIP $_{2}$ labeling appears to be very similar to that reported in SPM. Therefore we suggest that the phosphorylation of B-50 may be an important factor in signal transduction through the nerve growth cone membrane.

During development of the CNS, outgrowing neurites with highly motile growth cones at their tips travel complex routes to find their synaptic targets. These nerve growth cones, bearing lamellipodia and filopodia, are thought to be essential for axonal guidance during maturation of the neuronal circuitry. Soluble

\footnotetext{
Received May 15, 1987; revised Aug. 18, 1987; accepted Sept. 29, 1987

The authors want to thank Marina de Wit, Ben Tilly, and Rian van der Most for their excellent technical assistance, and Ed Kluis for preparing the figures.

Correspondence should be addressed to P. N. E. De Graan, Division of Molecular Neurobiology, Rudolf Magnus Institute for Pharmacology and Institute of Molecular Biology and Medical Biotechnology, University of Utrecht, Padualaan $8,3584 \mathrm{CH}$ Utrecht, The Netherlands

Copyright (c) 1988 Society for Neuroscience $0270-6474 / 88 / 051789-07 \$ 02.00 / 0$
}

factors (Connolly et al., 1985; Meinertzhagen, 1985; Belardetti et al., 1986), substrate adhesion (Kuwada, 1986; Van den Pol et al., 1986), and electrical fields (Freeman et al., 1985; Cohan and Kater, 1986) have all been reported to influence growth cone shape and movement. Growth cones bear a great diversity of glycoprotcins, surfacc molcculcs that may contributc to their path-finding ability, presumably by mediating intercellular interactions, including recognition (Greenberger and Pfenninger, 1986). The transduction mechanisms by which these various signals influence the membrane are not known. Only recently, procedures have been developed to isolate nerve growth cones from fetal (Pfenninger et al., 1983) or neonatal (Gordon-Weeks and Lockerbie, 1984) rat brain, which allows biochemical studies on signal-transduction systems. The first indication for the presence of $\mathrm{Ca}^{2+}$ - and cAMP-producing signal-transduction systems in isolated nerve growth cones was obtained by the group of Pfenninger, who showed $\mathrm{Ca}^{2+}$ - and cAMP-dependent phosphorylation of a number of phosphoprotein bands in fetal nerve growth cones (Ellis et al., 1985; Katz et al., 1985).

One of the most prominent phosphoproteins in nerve growth cones is B-50 (De Graan et al., 1985; Katz et al., 1985; Skene et al., 1986). This neuron-specific phosphoprotein, B-50 $\left(M_{\mathrm{r}} 48\right.$ $\mathrm{kDa}$, IEP 4.5), belongs to a family of growth-associated proteins (Skene and Willard, 1981; Willard et al., 1985) and appears to be identical to GAP43 (Jacobson et al., 1986; Zwiers et al., 1987), GAP48 (Benowitz and Lewis, 1983; Perrone-Bizzozero et al., 1986), pp46 (Meiri et al., 1986), and Fl (Gispen et al., 1986). Recently, the cloning of complementary DNA for GAP43 and its primary structure has been reported (Basi et al., 1987; Karns et al., 1987). Several reports from different laboratories indicate a developmental regulation of B-50 expression. In rat brain the B-50 content is high at birth, but decreases as the brain matures and ages (Zwiers et al., 1987). In cortical cultures, metabolic labeling of B-50 is a prominent correlate of neurite outgrowth (Perrone-Bizzozero et al., 1986). Metabolic labeling during regenerative axonal sprouting showed increases in the incorporation of label into GAP43 up to 100 -fold, in contrast to other proteins (Skene and Willard, 1981; Redshaw and Bisby, 1984; Perry et al., 1987). Increased B-50 levels are associated with recovery of the sciatic nerve from injury (Verhaagen et al., 1986) and with NGF-induced neurite outgrowth in pheochromocytoma PC12 cells (Van Hooff et al., 1986). Immunocytochemical studies show strong B-50/GAP43 immunoreactivity in outgrowing neurites of neonatal hippocampus and cerebellum in situ (Oestreicher and Gispen, 1986), of cultured PC12 cells (Van Hooff et al., 1986), and of cultured dorsal root ganglion cells (Meiri et al., 1986). Moreover, neuronal sprouts of the regenerating sciatic nerve show marked immunoreactivity with 
affinity-purified anti-B-50 IgGs, whereas intact nerves are devoid of staining (Verhaagen et al., 1986). In the developing rat brain, $4 \beta$-phorbol 12,13-dibutyrate (PDB)-binding studies reveal high protein kinase $\mathrm{C}$ (PKC) levels in differentiating neurite-dense layers compared to regions with mitotic cell bodies (Murphy et al., 1983). The association of the B-50 kinase, PKC, with neuronal processes suggests involvement of $\mathrm{PKC}$ phosphorylation in neuritogenesis.

In adult rat brain, the B-50 protein has been implicated in the modulation of receptor-mediated phosphatidylinositol 4,5bisphosphate $\left(\mathrm{PIP}_{2}\right)$ hydrolysis (Gispen et al., 1985b). Receptormediated breakdown of PIP ${ }_{2}$ generates the second messengers inositol trisphosphate $\left(\mathrm{IP}_{3}\right)$ and diacylglycerol (DG) (Berridge and Irvine, 1984). The formation of DG results in the activation of $\mathrm{PKC}$, and $\mathrm{IP}_{3}$ is thought to mobilize $\mathrm{Cd}^{2+}$ from intracellular stores. In synaptosomal plasma membranes (SPM) prepared from adult rat brain, B-50 is a major substrate of PKC (Aloyo et al., 1982, 1983) and is phosphorylated by endogenous PKC (Eichberg et al., 1986). Receptor-mediated hydrolysis of $\mathrm{PIP}_{2}$, resulting in activation of $\mathrm{PKC}$, increases the degree of phosphorylation of B-50. Subsequently, phosphorylated B-50 is thought to inhibit PIP-kinase activity (Van Dongen et al., 1985), thereby modulating the amount of $\mathrm{PIP}_{2}$ available for further hydrolysis and thus closing a feedback loop. In adult rat brain, $\mathrm{ACTH}_{1-24}$ reduces $\mathrm{B}-50$ phosphorylation and concomitantly stimulates formation of $\mathrm{PIP}_{2}$ (Jolles et al., 1981). These studies indicate that B-50 might be involved in signal transduction of neuronal membranes in adult rat brain.

In this paper we show that $\mathrm{B}-50$ is a substrate of $\mathrm{PKC}$ in nerve growth cones from fetal rat brain and that these growth cones contain the major components of the feedback system proposed for adult SPM. Furthermore, we present evidence that, in nerve growth cone membranes, there also exists an inverse relationship between the degree of $\mathrm{B}-50$ phosphorylation and $\mathrm{PIP}_{2}$ labeling.

\section{Materials and Methods}

Tissue fractionation. Growth cone particulate material (GCp) was prepared from fetal rat brains that were removed after $17-19 \mathrm{~d}$ of gestation (Pfenninger et al., 1983; De Graan et al., 1985). SPM from adult rat brain were prepared as described by Kristjansson et al. (1982). The GCp or SPM preparations were used fresh or stored in $10 \%$ glycerol at $-80^{\circ} \mathrm{C}$. Protein was determined according to the method of Lowry et al. (1951), using BSA as a standard.

Phosphorylation assay. Endogenous phosphorylation activity in $\mathrm{GCp}$ and SPM was assayed essentially as described previously (Kristjansson et al., 1982). The reaction mixture consisted of 10-15 $\mu$ g protein, 7.5 $\mu \mathrm{M} / 2 \mu \mathrm{Ci} \gamma{ }^{32} \mathrm{P}$-ATP (sp act, $3000 \mathrm{Ci} / \mathrm{mmol}$; Amersham, UK), in buffer A (10 mM Tris- $\mathrm{HCl}, \mathrm{pH} 7.4,10 \mathrm{~mm} \mathrm{MgCl}$, and $0.1 \mathrm{mM} \mathrm{CaCl}_{2}$ ), in buffer B (10 mM Na+acetate, $10 \mathrm{mM} \mathrm{Mg}^{2+}$-acetate, $0.1 \mathrm{mM} \mathrm{Ca}^{2+}$-acetate, $\mathrm{pH}$ 6.5) for $\mathrm{ACTH}_{1-24}$ incubations or in buffer C (20 mM HEPES, pH $7.4,10 \mathrm{mM} \mathrm{Na}^{+}$-acetate, $10 \mathrm{mM} \mathrm{Mg}^{2+}$-acetate, $80 \mathrm{~mm} \mathrm{KCl}, 1 \mathrm{~mm}$ EGTA, $0.9 \mathrm{mM} \mathrm{Ca}^{2+}$-acetate) for phorbol diester incubations (Eichberg et al., 1986). After $5 \mathrm{~min}$ preincubation at $30^{\circ} \mathrm{C}$, the phosphorylation reaction was started by addition of ATP. ACTH ${ }_{1-24}$ was added $15 \mathrm{sec}$ and phorbol diesters 75 sec prior to the ATP. In some experiments, partially purified PKC $(2 \mu \mathrm{l}$; Aloyo et al., 1983) was added at the start of the preincubation. The final incubation volume was $25 \mu \mathrm{l}$. Inactivation of endogenous enzyme activities was performed by heating the protein samples for 5 $\min$ at $100^{\circ} \mathrm{C}$. The protein phosphorylation reaction was stopped after $15 \mathrm{sec}$ by addition of a SDS-denaturing solution (Zwiers et al., 1976), and lipid phosphorylation by addition of $2 \mathrm{ml}$ ice-cold chloroform/ methanol/12 $N$ HCl (200:100:0.75; vol/vol/vol) (Jolles et al., 1981).

Quantitative and qualitative analyses of phosphorylation. Denatured proteins were separated on $11 \%$ SDS-polyacrylamide slab gels (Kristjansson et al., 1982). After protein staining with fast green, gels were dried and subjected to autoradiography. ${ }^{32} \mathrm{P}$-incorporation was deter- mined by densitometric scanning of the autoradiograms and by liquidscintillation counting of the B-50 protein excised from the gel (Wiegant et al., 1978). Lipids were extracted from the reaction mixture and quantitatively separated by thin-layer chromatography (TLC) (Jolles et al., 1981). Lipid spots on TLC plates were visualized with iodine vapor and by autoradiography. The ${ }^{32} \mathrm{P}$-labeled spots were scraped from the plates, and radioactivity was measured by liquid-scintillation counting. Data were analyzed by ANOVA with a supplemental $t$ test.

Immunoprecipitation and peptide mapping. Immunoprecipitation was performed as described previously (Van Hooff et al., 1986). In brief, phosphorylated samples were diluted in detergent containing buffer with rabbit anti-B-50 (antiserum 8502) or preimmune serum in a final dilution of 1:200. Immunoprecipitates were analyzed by SDS-PAGE and autoradiography. B-50 immunoprecipitates from GCp and from SPM (equal number of counts) were subjected to limited proteolysis with Staphylococcus aureus protease V8 (SAPV8), as described previously (Van Hooff et al., 1986).

Immunoblotting. GCp and SPM proteins were electrophoretically separated on $11 \%$ SDS-polyacrylamide slab gels. Separated proteins were transferred to nitrocellulose and stained with amido black, with affinitypurified anti-B-50 IgGs (antiserum 8103, dilution 1:2000), affinity-purified anti-PIP-kinase IgGs (Van Dongen et al., 1986; dilution 1:2000), or preimmune IgGs (for procedure, see Schrama et al., 1984).

\section{Results}

\section{$B$-50 protein}

Recently, we demonstrated that a $48 \mathrm{kDa}$ phosphoprotein in GCp is indistinguishable from B-50 in SPM in terms of molecular weight, IEP, and the cross-reactivity with anti-B-50 IgGs (De Graan et al., 1985). The identity of this $48 \mathrm{kDa}$ GCp protein is now further substantiated by immunoprecipitation and peptide mapping (Fig. 1). Endogenous phosphorylation of GCp proteins with $\gamma-{ }^{32} \mathrm{P}$-labeled ATP reveals 2 major phosphoprotein bands with apparent molecular weights $\left(M_{\mathrm{r}}\right)$ of 48 and $87 \mathrm{kDa}$, respectively (Fig. 11, lanes A). Anti-B-50 antiserum, raised against B-50 purified from adult rat brain, selectively precipitates the $48 \mathrm{kDa}$ phosphoprotein from GCp and SPM (Fig. 1I, lanes B), whereas preimmune serum does not (Fig. 1I, lanes C). Limited proteolysis of the B-50 immunoprecipitates from SPM and GCp with SAPV8 generates identical phosphopeptide maps, with major fragments of 15 and $28 \mathrm{kDa}$, respectively (Fig. $1 I I)$. The $M_{\mathrm{r}} \mathrm{s}$ of these fragments are identical to those of the 2 major phosphofragments obtained by SAPV8 treatment of partially purified (Oestreicher et al., 1984; Zwiers et al., 1985) and purificd (unpublished observations) B-50. Thus, on the basis of all criteria tested so far, the $48 \mathrm{kDa}$ protein in $\mathrm{GCp}$ is identical to $\mathrm{B}-50$ in SPM.

\section{B-50 phosphorylation}

In adult rat brain, $\mathrm{B}-50$ is phosphorylated by the $\mathrm{Ca}^{2+}$ - and phospholipid-dependent PKC (Aloyo et al., 1982, 1983). To investigate whether B-50 in GCp is also a substrate of PKC, GCp proteins were phosphorylated with and without exogenous PKC. Endogenous B-50 phosphorylation in GCp and SPM (Fig. 2 , lanes $A$ ) is enhanced by the addition of purified PKC (Fig. 2, lanes B). In heat-inactivated GCp and SPM, the B-50 protein is one of the major substrates of purified PKC (Fig. 2, lanes C). In $\mathrm{GCp}$ the phosphorylation of several other phosphoprotein bands also increases upon addition of PKC. The estimated $M_{\mathrm{r}} \mathrm{s}$ of these PKC substrates in GCp are $87,40-45$, and $35 \mathrm{kDa}$. SPM also contains the $87 \mathrm{kDa}$ PKC substrate, which might be the $87 \mathrm{kDa}$ PKC substrate described by Wu et al. (1982), and, in addition, contains 2 low-molecular-weight PKC substrates ( $M_{\mathrm{r}} \pm 18$ and $\pm 22 \mathrm{kDa}$, respectively). The $35 \mathrm{kDa}$ PKC substrate in $\mathrm{GCp}$ is not present in SPM. Although these data show that 


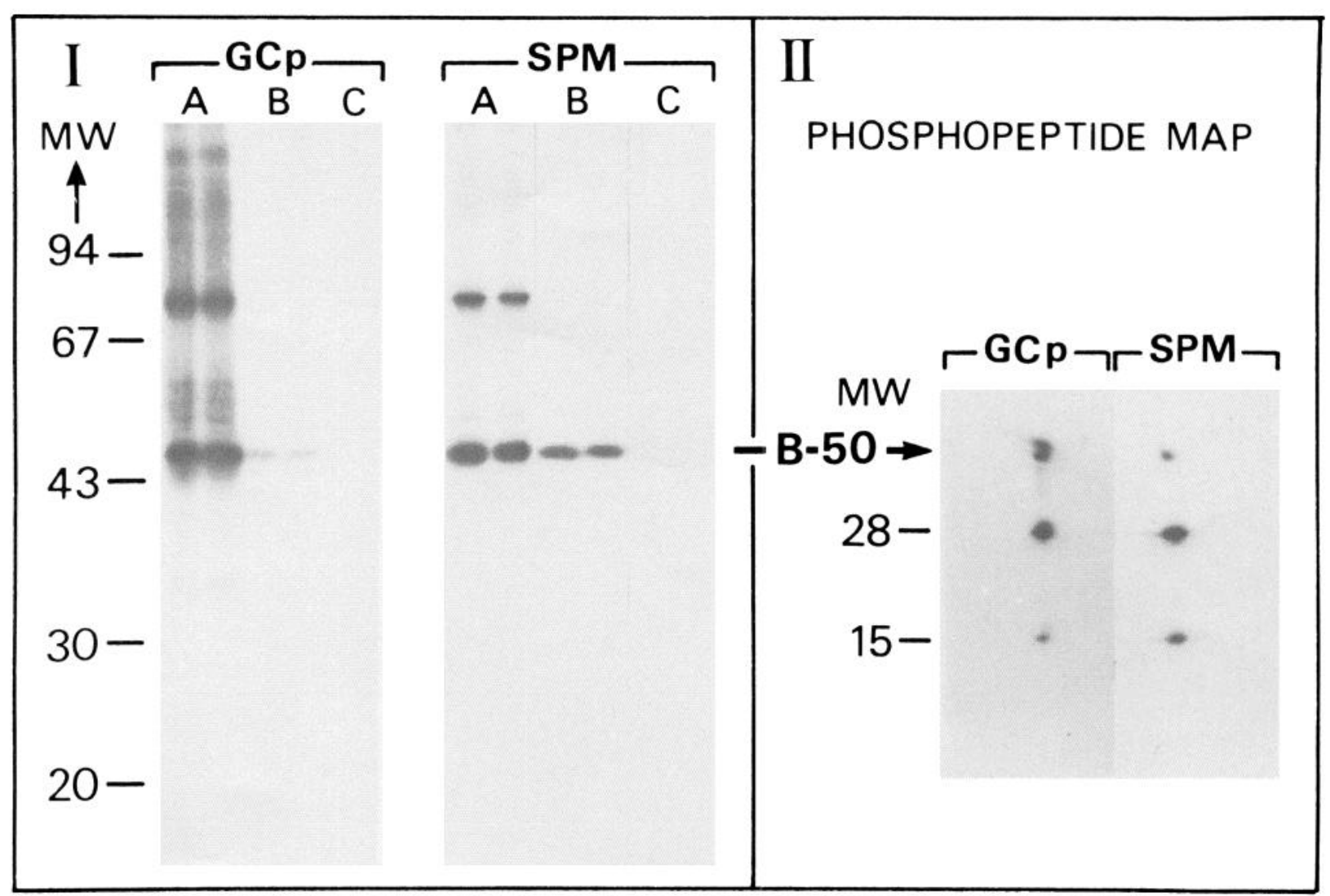

Figure 1. Immunoprecipitation and phosphopeptide mapping of B-50 from GCp and SPM. I, Autoradiogram of phosphorylated GCp and SPM proteins. Proteins $\left(10 \mu \mathrm{g} /\right.$ assay, stored at $\left.-80^{\circ} \mathrm{C}\right)$ were phosphorylated with ${ }^{32} \mathrm{P}$-ATP, separated on $11 \%$ SDS-gels, and subjected to autoradiography, before (lanes $A$ ) and after (lanes $B$ ) immunoprecipitation with anti-B-50 antiserum or (lanes $C$ ) preimmune serum. II, Autoradiogram of SAPV8treated phosphorylated GCp and SPM B-50 immunoprecipitates (I, lanes $B$ ).

B-50 in GCp is a substrate of PKC, they do not prove that PKC is the endogenous kinase.

To provide more evidence that PKC is the endogenous B-50 kinase, we tested the effect of phorbol diesters, known to stimulate PKC, on B-50 phosphorylation in GCp. PDB stimulated B-50 phosphorylation in a dose-dependent manner (Fig. 3). The minimal effective dose of PDB was $10^{-8}$ M. $4 \alpha$-Phorbol 12,13didecanoate ( $4 \alpha-\mathrm{PDD}$ ), which does not stimulate PKC activity, has no effect on B-50 phosphorylation (Fig. 3).

\section{Modulation by $\mathrm{ACTH}$}

In adult rat brain SPM, B-50 phosphorylation is inhibited by addition of $\mathrm{ACTH}_{1-24}$. B-50 phosphorylation in GCp is also inhibited by $\mathrm{ACTH}_{1-24}$ (Fig. 4). Half-maximal inhibition $\left(\mathrm{IC}_{50}\right)$ in GCp is reached at $5 \times 10^{-6} \mathrm{M}$. The $\mathrm{IC}_{50}$ for $\mathrm{ACTH}_{1-24}$-induced inhibition of B-50 phosphorylation in SPM $\left(2 \times 10^{-6} \mathrm{M}\right)$ does not differ significantly from that in GCp (Fig. 4), since statistical analysis of the regression lines revealed no difference in slope or intercept. This indicates that the mechanism of the ACTHinduced inhibition of B-50 phosphorylation in GCp and SPM is similar. Subsequently, we tested the effect of ACTH analogs and fragments, which are known to stimulate peripheral nerve regeneration (Bijlsma et al., 1981), on B-50 phosphorylation in GCp. ACTH $\mathrm{AC}_{1-16}, \alpha-\mathrm{MSH}$, and ORG2766 $\left(10^{-4}-10^{-5} \mathrm{M}\right)$ do not affect B-50 phosphorylation in GCp (results not shown). B-50 phosphorylation in SPM is inhibited by $\mathrm{ACTH}_{1-16}$ and $\mathrm{ACTH}_{1-13}$ (Zwiers et al., 1978), but not by $\alpha$-MSH or ORG2766 (unpublished observations).

\begin{tabular}{|c|c|c|c|c|c|c|}
\hline Addition (M) & PA & $\%$ & PIP & $\%$ & $\mathrm{PIP}_{2}$ & $\%$ \\
\hline \multicolumn{7}{|l|}{ ACTH } \\
\hline 0 & $1.95 \pm 0.18$ & 100 & $6.22 \pm 0.56$ & 100 & $0.63 \pm 0.09$ & 100 \\
\hline $10^{-5}$ & $1.34 \pm 0.30$ & 69 & $5.63 \pm 0.63$ & 90 & $1.03 \pm 0.07$ & $164^{*}$ \\
\hline $3 \times 10^{-5}$ & $1.29 \pm 0.10$ & 66 & $5.11 \pm 0.46$ & 82 & $1.16 \pm 0.08$ & $184 *$ \\
\hline $10^{-4}$ & $1.71 \pm 0.26$ & 88 & $5.37 \pm 0.92$ & 86 & $2.32 \pm 0.19$ & $368^{*}$ \\
\hline
\end{tabular}

Results are expressed as fmol phosphate/ $\mu \mathrm{g}$ protein per $15 \mathrm{sec} \pm$ SEM and as the percentage of control incubation without ACTH (\%). $n=6$.

* Significantly different from controls without $\mathrm{ACTH}_{1-24} ; p<0.01$. 


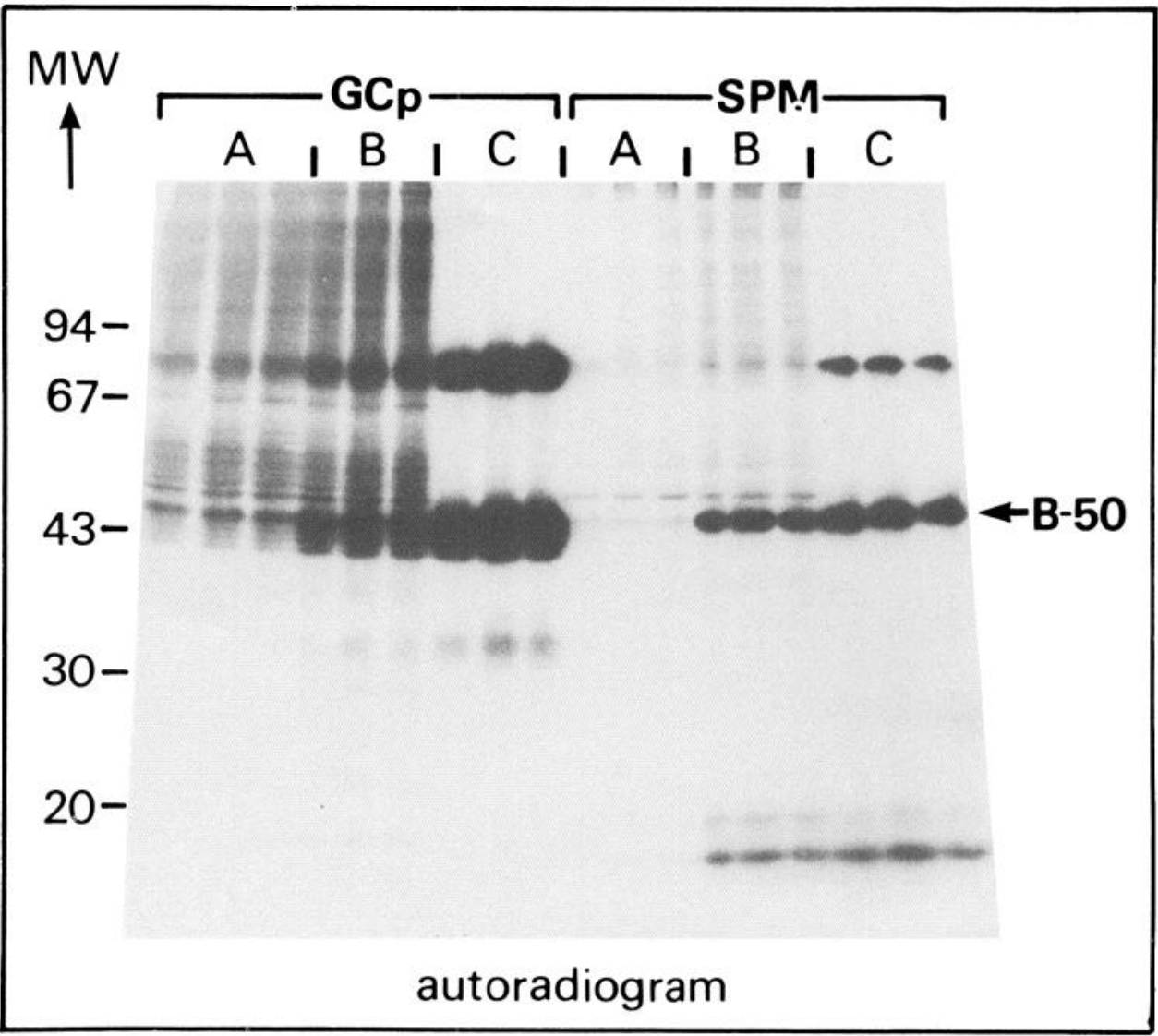

In adult rat brain, $\mathrm{ACTH}_{1-24}$ not only influences B-50 phosphorylation, but also increases the $\mathrm{PIP}_{2}$ labeling. This increase in PIP ${ }_{2}$ labeling is not caused by a direct effect of ACTH on PIP-kinase, but rather by an indirect effect on PIP-kinase elicited by a decrease in the phosphorylation state of B-50 (Gispen et al., 1985b). The presence of PIP-kinase, the rate-limiting enzyme in $\mathrm{PIP}_{2}$ formation, was investigated in GCp using affinitypurified rabbit IgGs directed against PIP-kinase that was puri-

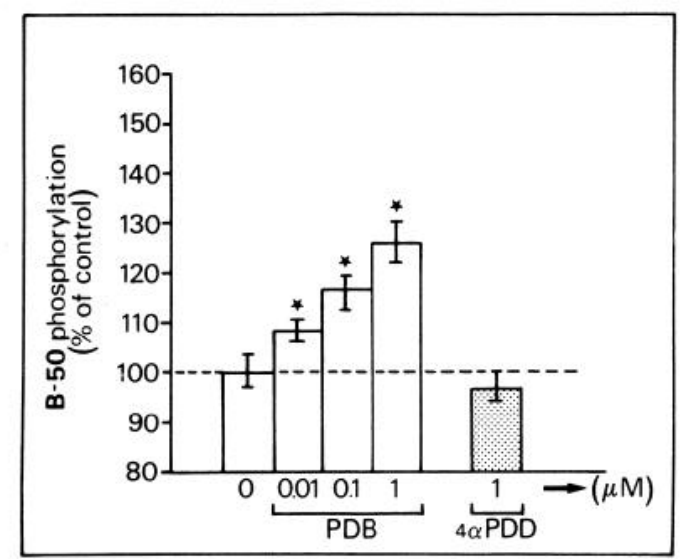

Figure 3. PDB stimulation of endogenous B-50 phosphorylation in GCp. GCp proteins $(10 \mu \mathrm{g}$, freshly prepared) were phosphorylated in the presence of different concentrations of PDB or $4 \alpha$-PDD. The B-50 band was excised from the SDS-gel and analyzed for ${ }^{32} \mathrm{P}$-incorporation by liquid scintillation counting. Data are expressed as percentage of controls \pm S.E.M. $(n=6)$. *Significantly different from control incubations without phorbol diesters $(p<0.05)$. fied from adult rat brain. Immunostaining of Western blots that were loaded with SDS-PAGE-separated SPM and GCp proteins (Fig. 5, lanes A, protein pattern) shows immunostaining of a 45 $\mathrm{kDa}$ protein in both preparations (Fig. 5, lanes B). Incubation of identical blots with anti-B-50 IgGs shows that the $45 \mathrm{kDa}$ band is distinct from B-50 (Fig. 5, lanes C). Preimmune IgGs do not cross-react with any of the GCp or SPM proteins (Fig. 5 , lanes D). This selective staining shows that PIP-kinase is

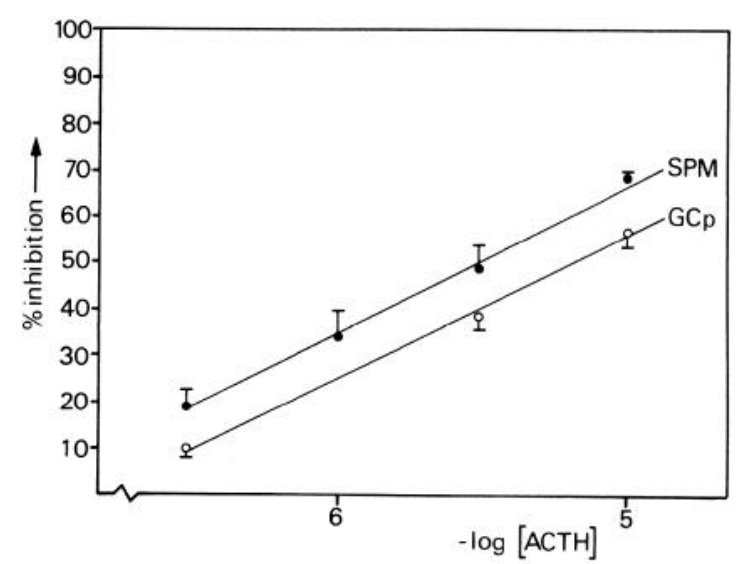

Figure 4. Dose-response curves of the $\mathrm{ACTH}_{1-24}$-induced inhibition of B-50 phosphorylation in GCp and in SPM. Proteins (10 $\mu \mathrm{g}$, freshly prepared) were phosphorylated in the presence of different concentrations of $\mathrm{ACTH}_{1-24}$. The B-50 band was excised from the SDS-gel and analyzed for ${ }^{32} \mathrm{P}$-incorporation by liquid-scintillation counting. Data are expressed as percentage inhibition as compared to controls without $\mathrm{ACTH}_{1-24} \pm$ SEM. 


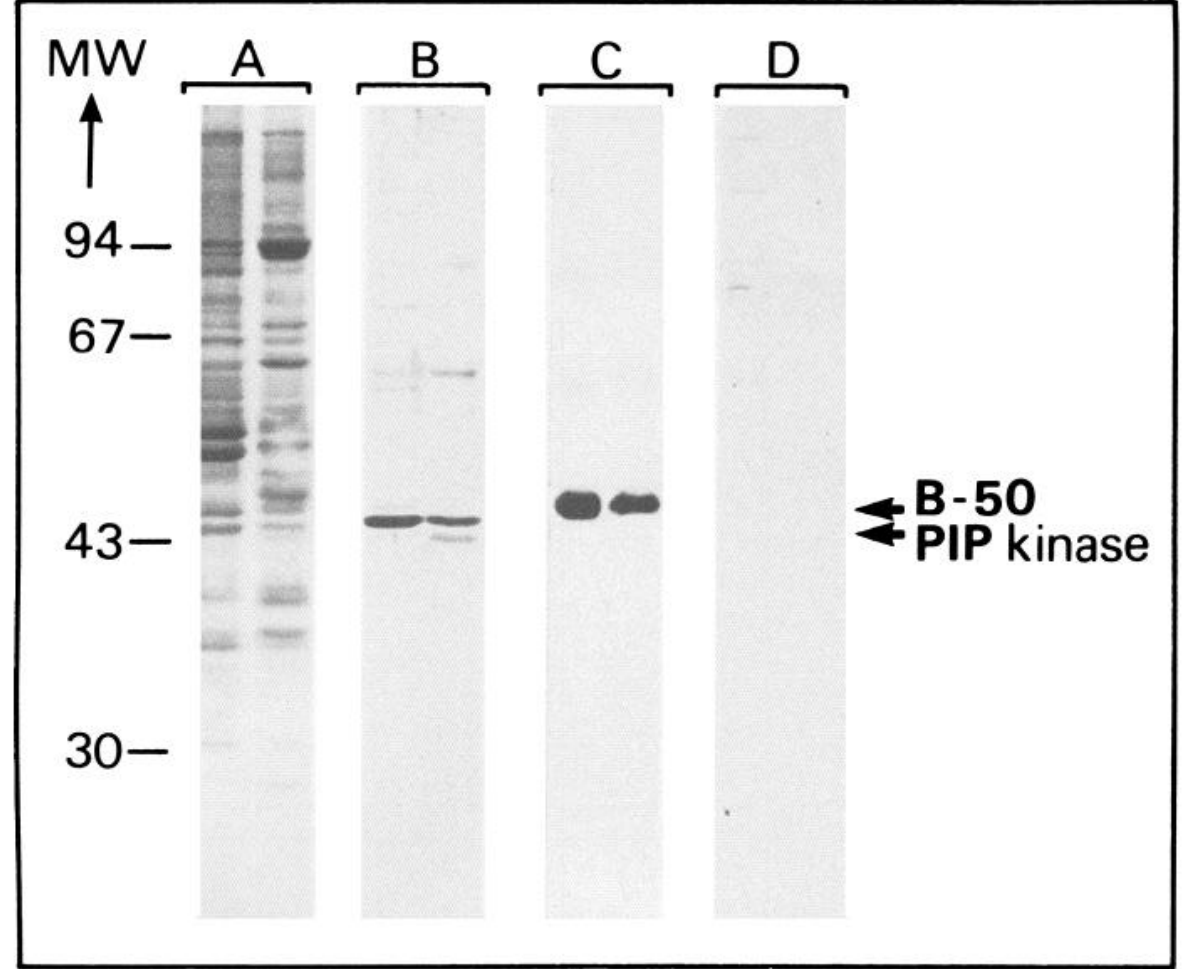

Figure 5. Immunostaining of Western blots of GCp and SPM proteins with anti-PIP-kinase and anti-B-50 antibodies. GCp proteins (left lanes, $A-D, 10$ $\mu \mathrm{g})$ and SPM proteins (right lanes, $A-$ $D, 10 \mu \mathrm{g}$ ) were separated on $11 \%$ SDSgels, blotted onto nitrocellulose, and subjected to amido black staining (lanes $A$ ), immunostaining with affinity-purified anti-PIP-kinase IgGs (lanes $B$ ), with affinity-purified anti-B-50 IgGs (lanes $C$ ), or with preimmune IgGs (lanes $D$ ). Molecular-weight markers $(M W)$ are indicated on the left. present in GCp. This is confirmed by the fact that endogenous phosphorylation of GCp with $\gamma-{ }^{32} \mathrm{P}$-labeled ATP results in ${ }^{32} \mathrm{P}$ incorporation into $\mathrm{PIP}_{2}$ (Fig. 6, Table 1). Other polyphosphoinositides (PPIs) labeled are phosphatidic acid (PA) and PIP. ${ }^{32} \mathrm{P}$-Incorporation in PIP is much higher than in $\mathrm{PIP}_{2}$. The addition of $\mathrm{ACTH}_{1-24}$ to GCp enhances the ${ }^{32} \mathrm{P}$-labeling of $\mathrm{PIP}_{2}$ in a dose-dependent manner, without affecting PA or PIP labeling (Fig. 6, Table 1). At $10^{-5} \mathrm{M} \mathrm{ACTH}_{1-24}, \mathrm{PIP}_{2}$ labeling increases with $64 \%$, whereas in SPM, the same concentration induces only a slight, though significant, increase in $\mathrm{PIP}_{2}$ labeling (Oestreicher et al., 1983).

\section{Discussion}

The enhanced B-50 level in neuronal tissue during neurite outgrowth (Meiri et al., 1986; Van Hooff et al., 1986; Verhaagen et al., 1986; Zwiers et al., 1987) suggests a specific role for B-50 in this process. In adult rat brain, B-50 is localized mainly in presynaptic terminals (Gispen et al., 1985a). It is, therefore, not very surprising that the growing axon tip or growth cone contains a similar $48 \mathrm{kDa}$ protein. Having compared these 2 proteins by means of 1-dimensional $\left(M_{\mathrm{r}}\right)$ and 2-dimensional (IEP) separation systems (De Graan et al., 1985), phosphopeptide mapping, immunostaining, and immunoprecipitation, we conclude that B-50 in GCp and SPM is identical.

Phosphorylation studies with exogenous $\mathrm{PKC}$ in native and heat-inactivated GCp strongly indicate that B-50 in GCp is a PKC substrate. The identity of the endogenous B-50 kinase is further substantiated by addition of phorbol diesters known to stimulate PKC activity (for a recent review, see Kikkawa and Nishizuka, 1986). 4 $\beta$-Phorbol diesters increase the B-50 phosphorylation in GCp in a dose-dependent manner (Fig. 3), with an effective dose range similar to that reported for B-50 in SPM (Eichberg et al., 1986). Furthermore, B-50 phosphorylation in GCp is dependent on the presence of $\mathrm{Ca}^{2+}$, but is not affected by addition of cAMP (Ellis et al., 1985; Katz et al., 1985; and C. O. M. Van Hooff, unpublished observations). It can be concluded that, as in SPM, B-50 is an endogencus substrate of PKC in GCP. However, the possibility cannot be excluded that other kinases, like the calcium-calmodulin protein kinase, as suggested by Katz et al. (1985), also phosphorylate B-50.

In adult rat brain, an inverse relationship was demonstrated, in a variety of paradigms, between changes in B-50 phosphorylation and the degree of $\mathrm{PIP}_{2}$ labeling (De Graan et al., 1986). On the basis of this inverse relationship, the presynaptic localization of B-50 (Gispen et al., 1985a), and the copurification of B-50, B-50-kinase, and PIP-kinase after extraction from SPM (Jolles et al., 1980), we have proposed a feedback model (Gispen et al., 1985b). Receptor-mediated breakdown of $\mathrm{PIP}_{2}$ will generate the second messengers $\mathrm{IP}_{3}$ and DG (Berridge and Irvine, 1984), of which the latter is known to enhance B-50 phosphorylation by activating PKC. A higher degree of B-50 phosphorylation inhibits PIP-kinase activity (Gispen et al., 1985b), thus decreasing the amount of $\mathrm{PIP}_{2}$ near the receptor, which will be available for further hydrolysis. Our data indicate that all components of such a feedback system, including B-50, PKC, PIPkinase, and $\mathrm{PIP}_{2}$, are present in GCp. Moreover, in GCp a first messenger, like ACTH, is able to modulate inversely B-50 phosphorylation and $\mathrm{PIP}_{2}$ formation in a dose-dependent manner (Figs. 4, 6, Table 1).

The fact that the dose-response curves for the inhibition of B-50 phosphorylation by ACTH in SPM and GCp are parallel indicates that the mechanism of action of ACTH in both developing and mature nerve terminal membranes is similar (Fig. 4). However, the physiological significance of this ACTH effect on B-50 phosphorylation is not well understood. In the peripheral nervous system, melanocortins such as ACTH are known to accelerate recovery from a crush lesion, e.g., in the sciatic nerve (Bijlsma et al., 1981). A prerequisite for this neurotrophic effect is application of the peptide during the early phase of 
Figure 6. Effect of $\mathrm{ACTH}_{1-24}$ on PPI metabolism in GCp. GCp (10 $\mu \mathrm{g}$ protein, freshly prepared) were phosphorylated with $\gamma-{ }^{32} \mathrm{P}$-ATP in the presence of different concentrations of $\mathrm{ACTH}_{1-24}$. Lipids were extracted, separated by thinlayer chromatography, and ${ }^{32} \mathrm{P}$-incorporation was visualized by autoradiography (exposure time, $20 \mathrm{hr}$ ).

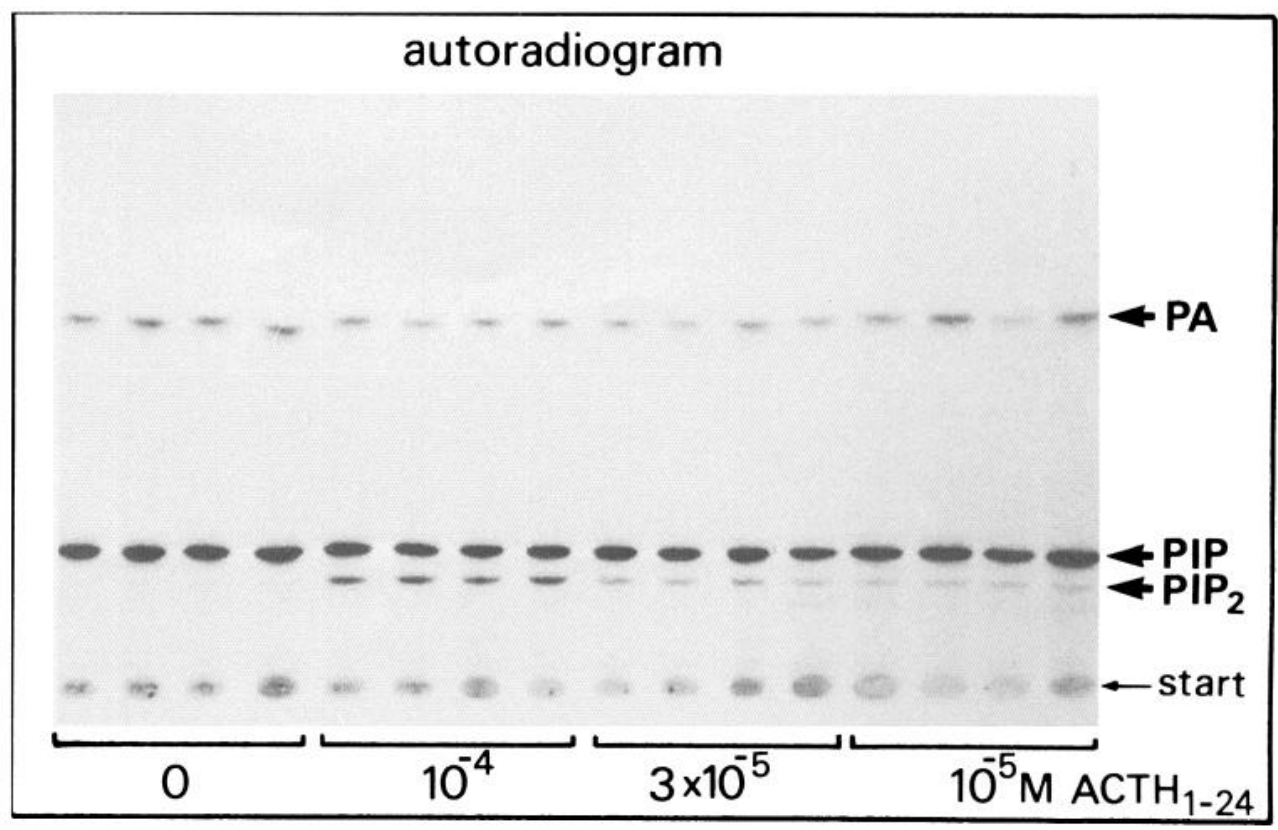

recovery, when active sprouting occurs. The mechanism by which these peptides exert their neurotrophic effects is not yet known. One might speculate that B-50 phosphorylation and PPI turnover are part of a signal-transduction mechanism by which the trophic action of ACTH is translated to the neuron. However, the peptide-structure requirements for the effect on neurite sprouting and on growth cone PKC inhibition differ and seem to suggest that the 2 events are not causally related. Apart from melanocortins, other growth cone guidance factors, such as soluble growth factors and surface proteins, may employ signaltransduction pathways involving the $\mathrm{PKC} / \mathrm{B}-50$ system.

\section{References}

Aloyo, V. J., H. Zwiers, and W. H. Gispen (1982) B-50 kinase and kinase $\mathrm{C}$ in rat brain. Prog. Brain Res. 56: 303-315.

Aloyo, V. J., H. Zwiers, and W. H. Gispen (1983) Phosphorylation of B-50 protein by calcium-activated, phospholipid-dependent protein kinase C and B-50 protein kinase. J. Neurochem. 41: 649-653.

Basi, G. S., R. D. Jacobson, I. Virag, J. Schilling, and P. Skene (1987) Primary structure and transcriptional regulation of GAP43, a protein associated with nerve growth. Cell 49: 785-791.

Belardetti, F., S. Schacher, E. R. Kandel, and S. A. Siegelbaum (1986) The growth cones of Aplysia sensory neurons: Modulation by serotonin of action potential duration and single potassium channel currents. Proc. Natl. Acad. Sci. USA 83: 7094-7098.

Benowitz, L. I., and E. R. Lewis (1983) Increased transport of 44,000 to 49,000 dalton acidic proteins during regeneration of the goldfish optic nerve: A two-dimensional gel analysis. J. Neurosci. 3: 21532163.

Berridge, M. J., and R. F. Irvine (1984) Inositol trisphosphate, a novel second messenger in cellular signal transduction. Nature 312: 315321.

Bijlsma, W. A., F. G. I. Jennekens, P. Schotman, and W. H. Gispen (1981) Effects of corticotrophin (ACTH) on recovery of sensorimotor function in the rat: Structure-activity study. Eur. J. Pharmacol. 76: 73-79.

Cohan, C. S., and S. B. Kater (1986) Suppression of neurite elongation and growth cone motility by electrical activity. Science 232 : 1638 1640.

Connolly, J. L., P. J. Seeley, and L. A. Greene (1985) Regulation of growth cone morphology by nerve growth factor: A comparative study by scanning electron microscopy. J. Neurosci. Res. 13: 183-199.
De Graan, P. N. E., C. O. M. Van Hooff, B. C. Tilly, A. B. Oestreicher, P. Schotman, and W. H. Gispen (1985) Phosphoprotein B-50 in nerve growth cones from fetal rat brain. Neurosci. Lett. 61: 235-241.

De Graan, P. N. E., A. B. Oestreicher, L. H. Schrama, and W. H. Gispen (1986) Phosphoprotein B-50: Localization and function. Prog. Brain Res. 69: 37-50.

Eichberg, J., P. N. E. De Graan, L. H. Schrama, and W. H. Gispen (1986) Dioctanoylglycerol and phorbol diesters enhance phosphorylation of phosphoprotein B-50 in native synaptic plasma membranes. Biochem. Biophys. Res. Commun. 136: 1007-1012.

Ellis, L., F. Katz, and K. H. Pfenninger (1985) Nerve growth cones isolated from fetal rat brain. II. Cyclic adenosine $3^{\prime}: 5^{\prime}$-monophosphate (cAMP)-binding proteins and cAMP-dependent protein phosphorylation. J. Neurosci. 5: 1393-1401.

Freeman, J. A., P. B. Manis, G. J. Snipes, B. N. Mayes, P. C. Samson, J. P. Wikswo, Jr., and D. B. Freeman (1985) Steady growth cone currents revealed by a novel circularly vibrating probe: A possible mechanism underlying neurite growth. J. Neurosci. Res. 13: 257-285.

Gispen, W. H., J. L. M. Leunissen, A. B. Oestreicher, A. J. Verkleij, and H. Zwiers (1985a) Presynaptic localization of B-50 phosphoprotein: The ACTH-sensitive protein kinase substrate involved in rat brain phosphoinositide metabolism. Brain Res. 328: 381-385.

Gispen, W. H., C. J. Van Dongen, P. N. E. De Graan, A. B. Oestreicher, and $\mathrm{H}$. Zwiers (1985b) The role of phosphoprotein B-50 in phosphoinositide metabolism in brain synaptic plasma membranes. In Inositol and Phosphoinositides, J. E. Bleasdale, J. Eichberg, and G. Hauser, eds., pp. 399-415, Humana Press, Clifton, NJ.

Gispen, W. H., P. N. E. De Graan, S. Y. Chan, and A. Routtenberg (1986) Comparison between the neural acidic proteins B-50 and F1. Prog. Brain Res. 69: 383-386.

Gordon-Weeks, P. R., and R. O. Lockerbie (1984) Isolation and partial characterization of neuronal growth cones from neonatal rat forebrain. Neuroscience 13: 119-136.

Greenberger, L. M., and K. H. Pfenninger (1986) Membrane glycoproteins of the nerve growth cone: Diversity and growth regulation of oligosaccharides. J. Cell Biol. 103: 1369-1382.

Jacobson, R. D., I. Virag, and J. H. P. Skene (1986) A protein associated with axon growth, GAP43, is widely distributed and developmentally regulated in rat CNS. J. Neurosci. 6: 1843-1855.

Jolles, J., H. Zwiers, C. J. Van Dongen, P. Schotman, K. W. A. Wirtz, and W. H. Gispen (1980) Modulation of brain polyphosphoinositide metabolism by ACTH-sensitive protein phosphorylation. Nature 286: 623-625.

Jolles, J., H. Zwiers, A. Dekker, K. W. A. Wirtz, and W. H. Gispen (1981) Corticotropin-(1-24)-tetracosapeptide affects protein phosphorylation and polyphosphoinositide metabolism in rat brain. Biochem. J. 194: 283-291. 
Karns, L. R., S. C. Ng, J. A. Freeman, and M. C. Fishman (1987) Cloning of complementary DNA for GAP43, a neuronal growthrelated protein. Science 236: 597-600.

Katz, F., L. Ellis, and K. H. Pfenninger (1985) Nerve growth cones isolated from fetal rat brain. III. Calcium-dependent protein phosphorylation. J. Neurosci. 5: 1402-1411.

Kikkawa, U., and Y. Nishizuka (1986) The role of PKC in transmembrane signalling. Annu. Rev. Cell Biol. 2: 149-178.

Kristjansson, G. I., H. Zwiers, A. B. Oestreicher, and W. H. Gispen (1982) Evidence that the synaptic phosphoprotein B-50 is localized exclusively in nerve tissue. J. Neurochem. 39: 371-378.

Kuwada, J. Y. (1986) Cell recognition by neuronal growth cones in a simple vertebrate embryo. Science 233: 740-746.

Lowry, O. H., N. J. Rosenbrough, W. L. Farr, and R. J. Randall (1951) Protein measurement with the Folin phenol reagent. J. Biol. Chem. 193: 265-275.

Meinertzhagen, I. A. (1985) Serotonin-containing cell charged with growth cone arrest. Nature 313: 348 .

Meiri, K. F., K. H. Pfenninger, and M. B. Willard (1986) Growth associated protein, GAP43, a polypeptide that is induced when neurons extend axons, is a component of growth cones and corresponds to $\mathrm{pp} 46$, a major polypeptide of a subcellular fraction enriched in growth cones. Proc. Natl. Acad. Sci. USA 83: 3537-3541.

Murphy, K. M. M., R. J. Gould, M. L. Oster-Granite, J. D. Gearhart, and S. H. Snyder (1983) Phorbol ester receptors: Autoradiographic identification in the developing rat. Science 222: 1036-1038.

Oestreicher, A. B., and W. H. Gispen (1986) Comparison of the immunocytochemical distribution of the phosphoprotein B-50 in the cerebellum and hippocampus of immature and adult rat brain. Brain Res. 375: 269-279.

Oestreicher, A. B., C. J. Van Dongen, H. Zwiers, and W. H. Gispen (1983) Affinity purified anti-B-50 protein antibody: Interference with the function of the protein B-50 in synaptic plasma membranes. J. Neurochem. 41: 331-340.

Oestreicher, A. B., M. Van Duin, H. Zwiers, and W. H. Gispen (1984) Cross-reaction of anti-rat B-50: Characterization and isolation of a "B-50 phosphoprotein" from bovine brain. J. Neurochem. 43: 935943.

Perrone-Bizzozero, N. I., S. P. Finklestein, and L. Benowitz (1986) Synthesis of a growth-associated protein by embryonic rat cerebrocortical neurons in vitro. J. Neurochem. 6: 3721-3730.

Perry, G. W., D. W. Burmeister, and B. Grafstein (1987) Fast axonally transported proteins in regenerating goldfish optic axons. J. Neurosci. 7: 792-806

Pfenninger, K. H., L. Ellis, M. P. Johnson, L. B. Friedrnan, and S. Somlo (1983) Nerve growth cones isolated from fetal rat brain: Subcellular fractionation and characterization. Cell 35: 573-584.

Redshaw, J. D., and M. A. Bisby (1984) Proteins of fast axonal transport in the regenerating hypoglossal nerve of the rat. Can. J. Physiol. Pharmacol. 62: 1387-1393.

Schrama, L. H., G. Weeda, P. M. Edwards, A. B. Oestreicher, and P. Schotman (1984) Multiple phosphorylation of pp30, a rat brain polyribosomal protein, sensitive to polyamines and corticotropin. Biochem. J. 224: 747-753.

Skene, J. H. P., and M. Willard (1981) Changes in axonally transported proteins during axon regeneration in toad retinal ganglion cells. $\mathbf{J}$. Cell Biol. 89: 86-95.

Skene, J. H. P., R. D. Jacobson, G. J. Snipes, C. B. McGuire, J. J. Norden, and J. A. Freeman (1986) A protein induced during nerve growth, "GAP43", is a major component of growth-cone membranes. Science 233: 783-786.

Van den Pol, A. N., U. di Porzio, and U. Rutishauser (1986) Growth cone localization of neural cell adhesion molecule on central nervous system neurons in vitro. J. Cell Biol. 102: 2281-2294.

Van Dongen, C. J., H. Zwiers, P. N. E. De Graan, and W. H. Gispen (1985) Modulation of the activity of purified phosphatidylinositol 4-phosphate kinase by phosphorylated B-50 protein. Biochem. Biophys. Res. Commun. 128: 1219-1227.

Van Dongen, C. J., J. W. Kok, L. H. Schrama, A. B. Oestreicher, and W. H. Gispen (1986) Immunochemical characterization of phosphatidylinositol 4-phosphate kinase from rat brain. Biochem. J. 233 . 859-864.

Van Hooff, C. O. M., P. N. E. De Graan, J. Boonstra, A. B. Oestreicher, M. H. Schmidt-Michels, and W. H. Gispen (1986) Nerve growth factor enhances the level of the PKC substrate B-50 in pheochromocytoma PC12 cells. Biochem. Biophys. Res. Commun. 139: 644 651

Verhaagen, J., C. O. M. Van Hooff, P. M. Edwards, P. N. E. De Graan, A. B. Oestreicher, P. Schotman, F. G. I. Jennekens, and W. H. Gispen (1986) The kinase C substrate protein B-50 and axonal regeneration. Brain Res. Bull. 17: 737-741.

Wiegant, V. M., H. Zwiers, P. Schotman, and W. H. Gispen (1978) Endogenous phosphorylation of rat brain synaptosomal plasma membranes in vitro: Some methodological aspects. Neurochem. Res. 3: $443-453$.

Willard, M. B., K. Meiri, and M. Glicksman (1985) Changes of state during neuronal development: Regulation of axon elongation. In $\mathrm{Mo}$ lecular Bases of Neural Development, G. M. Edelman, W. E. Gall, and W. M. Cowan, eds., pp. 341-361, Wiley, New York.

Wu, W. C.-S., S. I. Walaas, A. C. Nairn, and P. Greengard (1982) Calcium/phospholipid regulates phosphorylation of a $M_{r}$ " 87 " substrate protein in brain synaptosomes. Proc. Natl. Acad. Sci. USA 79. 5249-5253.

Zwiers, H., H. D. Veldhuis, P. Schotman, and W. H. Gispen (1976) ACTH, cyclic nucleotides and brain protein phosphorylation in vitro. Neurochem. Res. 1: 669-677.

Zwiers, H., V. M. Wiegant, P. Schotman, and W. H. Gispen (1978) ACTH-induced inhibition of endogenous rat brain protein phosphorylation in vitro: Structure activity. Neurochem. Res. 3: 455-463.

Zwiers, H., J. Verhaagen, C. J. Van Dongen, P. N. E. De Graan, and W. H. Gispen (1985) Resolution of rat brain synaptic phosphoprotein B-50 into multiple forms by two-dimensional electrophoresis; Evidence for multisite phosphorylation. J. Neurochem. 44: 10831090.

Zwiers, H., A. B. Oestreicher, M. A. Bisby, P. N. E. De Graan, and W. $H$. Gispen (1987) PKC substrate B-50 in adult and developing rat brain is identical to axonally-transported GAP43 in regencrating peripheral rat nerve. In Axonal Transport, M. A. Bisby and R. S. Smith, eds., pp. 385-406, Liss, New York. 